\title{
Diversity of Microbial Species Implicated in Keratitis: A Review
}

\author{
Elisabeth Karsten ${ }^{1}$ Stephanie LousieWatson, ${ }^{2,3}$ and Leslie John Ray Foster ${ }^{*}$
}

\author{
${ }^{1}$ Bio/Polymer Research Group, Centre for Advanced Macromolecular Design, School of Biotechnology and \\ Biomolecular Sciences, Faculty of Science and ${ }^{2}$ School of Medical Sciences, Faculty of Medicine, University of New \\ South Wales, Sydney and ${ }^{3}$ Save Sight Institute, University of Sydney, Sydney, Australia
}

\begin{abstract}
Background: Microbial keratitis is an infectious disease of the cornea characterised by inflammation and is considered an ophthalmic emergency requiring immediate attention. While a variety of pathogenic microbes associated with microbial keratitis have been identified, a comprehensive review identifying the diversity of species has not been completed.

Methods: A search of peer-reviewed publications including case reports and research articles reporting microorganims implicated in keratitis was conducted. Search engines including PubMed, Scopus and Web of Science with years ranging from 1950-2012 were used.

Results: 232 different species from 142 genera, representing 80 families were found to be implicated in microbial keratitis. Fungi exhibited the largest diversity with 144 species from 92 genera. In comparison, 77 species of bacteria from 42 genera, 12 species of protozoa from 4 genera and 4 types of virus were identified as the infectious agents. A comparison of their aetiologies shows reports of similarities between genera.

Conclusions: The diversity of microbial species implicated in keratitis has not previously been reported and is considerably greater than suggested by incidence studies. Effective treatment is heavily reliant upon correct identification of the responsible microorganisms. Species identification, the risk factors associated with, and pathogenesis of microbial keratitis will allow the development of improved therapies. This review provides a resource for clinicians and researchers to assist in identification and readily source treatment information.
\end{abstract}

Keywords: Microbial Keratitis, Staphylococcus, Amoebic Keratitis, Acanthamoeba, Mycotic keratitis, Fusarium, Candida, Herpetic keratitis, HSV-1.

\section{BACKGROUND}

Microbial keratitis is an infectious disease of the cornea that is characterised by inflammation, often with stromal infiltration by leukocytes, and is considered an ophthalmic emergency requiring immediate attention. Both infectious and immune mechanisms are important in the development of this sight threatening condition [1, 2]. Keratitis can progress rapidly with corneal destruction through pathological wound healingwithin 24-48 hours [3-5]. A decade-old estimate for keratitis induced corneal ulcers of approximately 2 million per annum in the developed world is likely to be conservative [4]. Permanent visual dysfunction has been reported in a significant number of patients in both developed and developing nations [6].

Initial management of microbial keratitis is empiric with broad-spectrum topical antimicrobials, as with current microbiological investigations it can take days or even weeks to identify a causative organism. This reliance on antimicrobials has been implicated in the emerging resistance in some countries to some of these commonly

*Address correspondence to this author at the Bio/polymer Research Group, School of Biotechnology \& Biomolecular Sciences, University of New South Wales, Sydney, NSW 2052, Australia; Tel: +61-2-9385-2054; Fax: +61-2-9313-6710; E-mail: J.Foster@unsw.edu.au used antimicrobial agents [7]. Furthermore, topical therapy has limitations, including their rapid loss caused by drainage and high tear turnover and ocular toxicity [8]. Patients with microbial keratitis continue to lose vision and suffer ocular pain and discomfort. Clearly, improved therapies for microbial keratitis are required, while a more rapid and correct identification of the infectious agent supports a more effective treatment.

A variety of pathogenic microbes have been associated with microbial keratitis [9], but to date a comprehensive review of the responsible microbes has not been performed. Identification of the responsible organisms, the risk factors associated with, and pathogenesis of microbial keratitis will allow the development of improved therapies. In this paper we identify and report the diversity of microbial species implicated in keratitis, as well their aetiologies and reported treatments.

\section{METHODS}

A systematic review of the current literature pertaining to the identity of organisms implicated in microbial keratitis was conducted. PubMed, Scopus and Web of Science searches were performed using the terms 'microbial keratitis', 'keratitis', 'bacterial keratitis', 'fungal keratitis', 'amoebic keratitis' and 'viral keratitis'. Searches were 
conducted within the year limits for each of the data bases; these were from 1950 for PubMed, 1950 for Scopus and 1950 for Web of Science. Searches were restricted to English Language.

Publications were read and information reporting identification of organisms implicated in microbial keratitis abstracted on the basis of (a) organisms identity, (b) aetiology and (c) treatment. The review objective was restricted to species diversity and did not aim to compile any incidence data.

\section{RESULTS AND DISCUSSION}

A range of microorganisms, including fungi, bacteria, protozoa, and viruses, have been identified as infectious agents in microbial keratitis. An exhaustive review of the literature to identify the species diversity revealed 232 different species from 142 genera, representing 80 families, although it is unclear which were opportunistic infections and whether any possess virulence factors that support the initiation of infection. Based on the literature, the greatest diversity of species associated with keratitis is fungal with 144 species from 92 genera. In comparison, 75 species of bacteria from 42 genera, 9 species of protozoa from 4 genera and 4 types of virus have been identified as the infectious agents in microbial keratitis (Fig. 1).

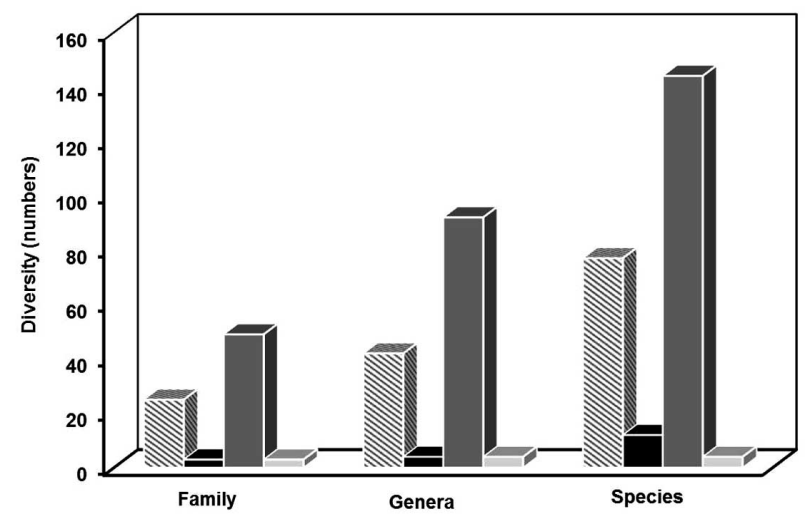

Fig. (1). Distribution of microorganisms associated with keratitis, at the family, genera and species levels based on the literature, amoebic $\mathbf{\square}$, bacterial $\mathbf{\square}$, viral $\square$ and fungal keratitis $\square$.

In total, 49 families were identified in fungal keratitis, with 2 being yeast and 47 filamentous (Table 1) while 25 families of bacteria were identified; of which 12 were Gram positive and 13 Gram negative (Table 2). In amoebic keratitis, 3 families, predominantly Acanthamoebidae, were identified (Table 5); while in viral keratitis the majority of reports were from the Herpesviridae family (Table 6). Risk factors and treatment for each type of keratitis were also identified in the review. The clinical symptoms of keratitis are similar despite the infectious agent and is characterised by local pain, lacrimation, and photophobia, however the clinical appearance of lesions can differ depending upon organism [10].

\section{Fungal Keratitis}

Mycotic keratitis, due to filamentary fungi, is typified by a grey-white infiltrate with irregular feathery margins and raised borders (Fig. 2a); along with suppuration, hypopyon,
Table 1. Number of Identified Families Implicated in Fungal Keratitis

\begin{tabular}{|c|c|c|}
\hline & Phylum & Number of Identified Families \\
\hline \hline \multirow{3}{*}{ Mycota } & Ascomyctoa & 38 \\
\cline { 2 - 3 } & Basididiomycota & 7 \\
\cline { 2 - 3 } & Zygomycota & 2 \\
\hline Slime Mold & Myxomycota & 1 \\
\hline Straminipila & Oomycota & 1 \\
\hline
\end{tabular}

Table 2. Number of Identified Families Implicated in Bacterial Keratitis

\begin{tabular}{|l|c|c|}
\hline & Phylum/Division & Number of Identified Families \\
\hline \hline \multirow{2}{*}{ Gram positive } & Actinobacteria & 7 \\
\cline { 2 - 3 } & Firmicutes & 5 \\
\hline \multirow{2}{*}{ Gram negative } & Proteobacteria & 12 \\
\cline { 2 - 3 } & Bacteroides & 1 \\
\hline Gram variable & $\mathrm{n} / \mathrm{a}$ & 0 \\
\hline
\end{tabular}

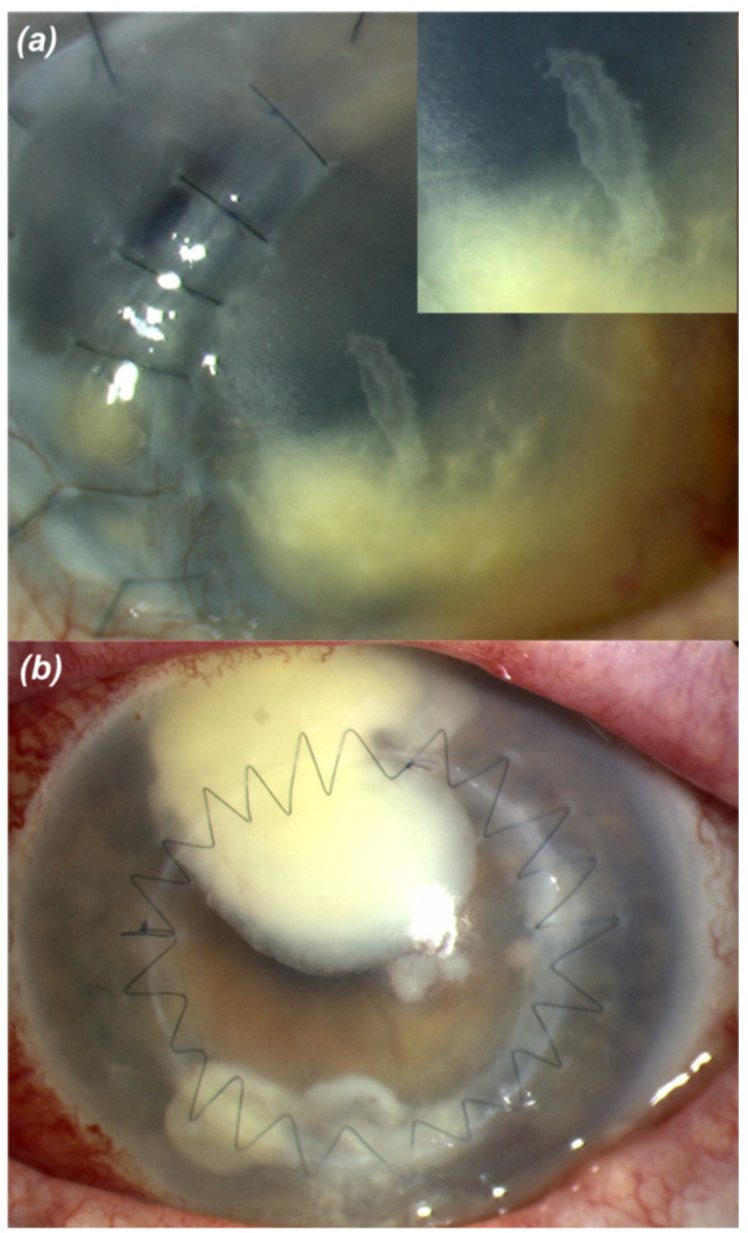

Fig. (2). Mycotic keratitis following corneal grafting with (a) filamentary, Aspergillus, Insert: higher magnification showing the irregular feathery margins, and (b) unicellular, Candida spp. 
satellite lesions, Descemet's fold, and an immune ring with minimal surrounding infiltrate [11]. Filamentous fungi such as Fusarium spp and Aspergillus spp are common in mycotic keratitis. However, aetiologies exhibited by unicellular fungi, such as yeasts of the Saccharomycetaceae and Tremellaceae families, are often clinically similar to those of bacterial keratitis (Fig. 2b) [12].

The majority of the identified organisms were 'true fungi' or Mycota; of 48 families identified, only 2 were not of this classification (Table 3). Cunninghamellaceae is a slime mold from the phylum Myxomycota and was reported by Wang et al. in 2009 from patients in central China [13]. Pythiaceae from the Straminipila, phylum Oomycota was reported by Sirikul et al. in 2008 from patients in Thailand [14]. From those within Mycota, the majority were of the phylum Ascomycota (Table 3).

Geographical location and climate are reported to influence the clinical presentation and outcome of fungal diseases, probably through changes in the causative agent [15]. Fusarium solani ocular infections are reported to have the most severe prognosis; its progression is comparatively rapid with patients demonstrating corneal perforation in only a few weeks [11]. In contrast, dematiaceous fungi such as Curvularia and Lasiodiplodia tend to result in persistent low-grade infection and may present with a slightly pigmented lesion [16, 17].

A range of treatments have been suggested for use in mycotic keratitis including natamycin [18-20], azoles such as fluconazole [21,22] and voriconazole [23], and amphotericin B [18, 24]. Kalavathy et al. [25] reported that the use of the antifungal natamycin (5\%) topically was the most ideal treatment available against filamentous fungi especially Fusarium spp. However the molecular weight of natamycin is relatively high (665.73 g.mol ${ }^{-1}$ ) and as a consequence it has low penetration into corneal tissue [26]. This may explain the reduced effectiveness of natamycin in treating deep mycosis as observed by Senupta et al. [27]. Galarreta et al. [21] has reported intensive use of topical econazole (1\%) to have efficacy against filamentary fungi such as Fusarium spp. While fluconazole has been used to treat yeast infections with significant results, Galarreta et al. [21] reports poor outcomes in treating filamentary fungi. The use of amphotericin B was prevalent in the past as a treatment for mycotic keratitis, especially caused by yeast; although a very effective treatment there are significant side effects associated with its use [28]. Hence, the use of amphotericin $\mathrm{B}$ as an initial treatment has significantly declined, but it may still be implemented as a secondary measure [29]. Recently, the clinical use of voriconazole has increased. It can be administered topically or systemically, and achieves high penetration into the cornea [23]. Clinically, voriconazole has been reported to be an effective treatment for mycotic keratitis [30, 31].

Although topical treatments with antifungal agents are moderately effective against either yeasts or filamentous fungi, they are by no means the optimal therapy due to their reduced corneal perforation. Systemic antifungals are typically given, along with topical therapy, particularly for deep infections and those close to the vascularised corneal limbus. If medical therapy fails then surgical invention is required. Xie et al. [32] reported that surgery was performed in $92.4 \%$ of patients with fungal keratitis, with only $7.6 \%$ controlled by topical mediations. Furthermore Saha et al. [33] reported that $59.4 \%$ of the patients required surgery, due to ineffective medical therapy.

\section{Bacterial Keratitis}

Bacterial keratitis commonly presents with an overlying epithelial defect and relatively less distinct cellular infiltrate and suppuration than fungal keratitis (Fig. 3). In addition, progression of bacterial infection tends to be slower than ophthalmic mycoses [34]. However Pseudomonas keratitis, most commonly occurring in association with contact lens wear, can progress rapidly and is identified by a considerable suppurative infiltrate and the presence of Gram-negative organisms [34].

Similar to fungal keratitis, the severity of bacterial infections is largely dependent upon the causative agent. Staphylococcus epidermidis [35], Streptococcus pneumoniae and Pseudomonas aeruginosa [36] are reported to be the most common pathogens associated with bacterial keratitis. Corneal infection with these pathogens can be quite severe; Kaye et al. [37] reported that the presence of S. pneumoniae was more often associated with permanent damage to the eye and $P$. aeruginosa infection has been found to progress rapidly to corneal perforation even with the rigorous use of antibiotics [38].

Of the 25 identified families, the distribution between Gram positive and Gram negative organisms is relatively even. However, apart from one family, Flavobacteriaceae, in the phylum Bacteroides, all other identified Gram negative organisms are from the phylum Proteobacteria (Table 4).

In the past 20 years fluoroquinolones such as ofloxacin and ciprofloxacin have been used as the primary treatment for bacterial keratitis [39]. More recently it has been suggested that the monotherapeutic use of fluoroquinolones in treating bacterial keratitis may have led to the development of resistance against the drug [7]. However there are conflicting reports regarding this issue. For example, Schaefer et al. [40] reported that most Gram negative and Gram positive bacteria were sensitive to fluoroquinolones, with the exception of some $S$. pneumoniae and Pseudomonas cases which remained resistant. Jhanji et al. [41] reported S. epidermidis isolated from an infected cornea was resistant to all fluoroquinolones used. In contrast, Shalchi et al. [42] has claimed no increasing resistance to fluoroquinolones and advised their continued use. It is also thought that systemic use of fluoroquinolones, rather than topical, may be responsible for resistance. Furthermore, Reviglio et al. suggests that topical application of fluroquinones promotes the expression of corneal metalloproteinases, the proteolytic properties of which can adversely affect the wound healing process [43].

It is important to note in treating keratitis that in vitro susceptibility testing rarely corresponds to the clinical reality $[44,45]$, as difficulties in regulating doses of topical treatments within the eye [46] and inaccurate breakpoints are used in in vitro susceptibility testing [37]. As the breakpoints being currently used assess the systemic administration of antibiotics as opposed to ocular topical administration, the resistance in ocular infections may be overestimated [37, 47]. 
Table 3. Diversity of Fungal Species Implicated in Keratitis $\left({ }^{1}\right.$ Previously Cephalosporium spp., ${ }^{2}$ Previously Monilia spp. - Species Not Identified)

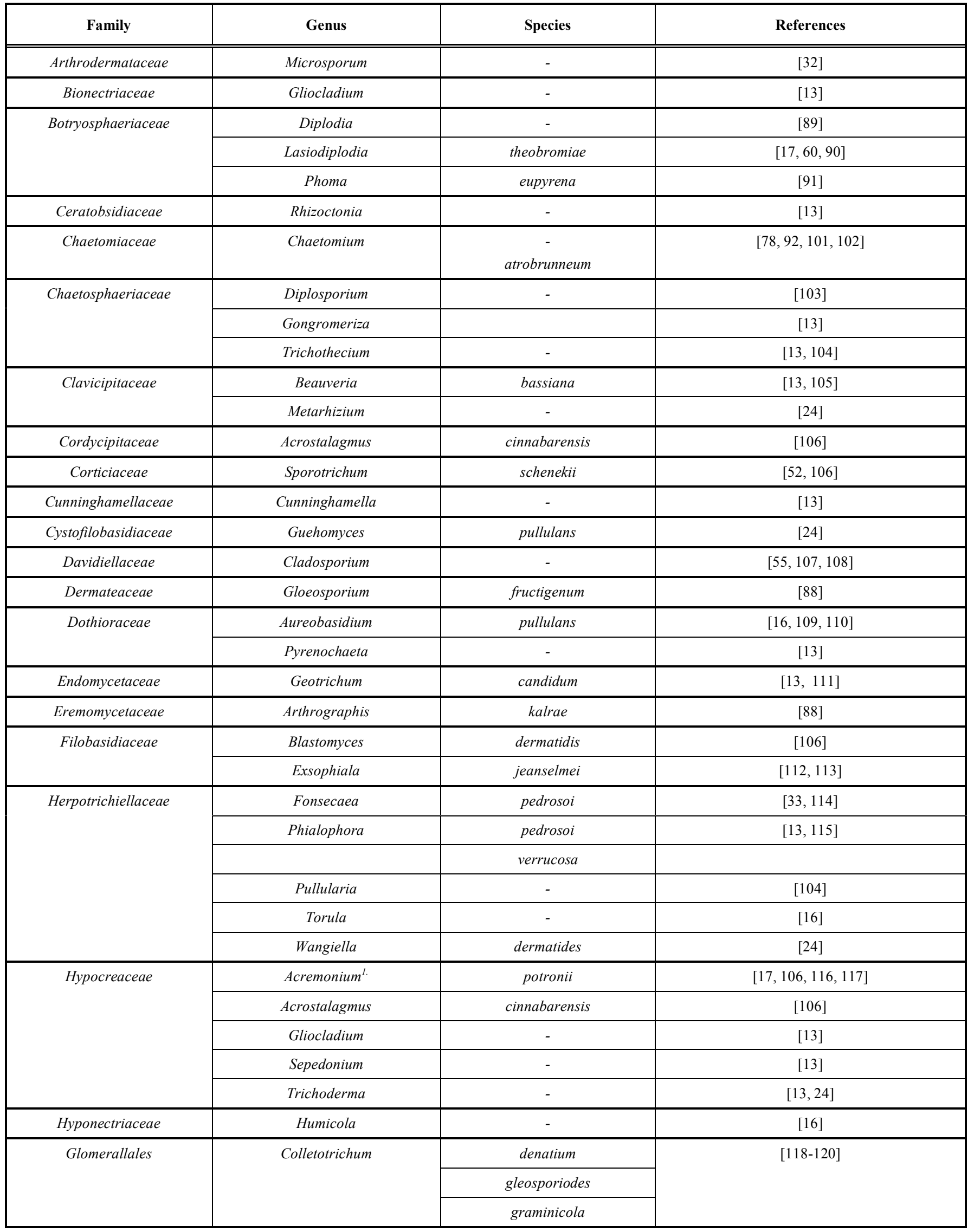


(Table 3) contd.....

\begin{tabular}{|c|c|c|c|}
\hline Family & Genus & Species & References \\
\hline Gymnoascaceae & Gymnoascus & - & {$[110]$} \\
\hline \multirow[t]{2}{*}{ Incertae sedis } & Scytalidium & hyalinum & [112] \\
\hline & Myrothecium & - & [111] \\
\hline Lasiosphaeriaceae & Monotospora & - & {$[13]$} \\
\hline Lophiostomataceae & Tetrapola & - & {$[121]$} \\
\hline Metacapnodiaceae & Hormiscium & - & {$[13]$} \\
\hline \multirow[t]{7}{*}{ Microascaceae } & Doratomyces & - & [13] \\
\hline & Monosporium & - & {$[108]$} \\
\hline & Pseudoallescheria & boydii & {$[32,89,112]$} \\
\hline & Scedosporium & apiospermum & {$[47,78,107]$} \\
\hline & & prolificans & \\
\hline & Scopularisopsis & blochi & {$[13,21,106]$} \\
\hline & & brevicaulis & \\
\hline \multirow[t]{5}{*}{ Mucoraceae } & Muсоr & cornealis & {$[32,106]$} \\
\hline & & racemosus & \\
\hline & Rhizopus & nigricans & {$[103,106,108]$} \\
\hline & & parasiticus & \\
\hline & Zygorhynchus & - & {$[13]$} \\
\hline \multirow[t]{2}{*}{ Mycospaerellaceae } & Cercospora & - & [13] \\
\hline & Hormodendrum & - & {$[82,103]$} \\
\hline \multirow[t]{18}{*}{ Nectricaceae } & Bactridium & - & {$[13]$} \\
\hline & Cylindrocarpon & lichenicola & {$[89]$} \\
\hline & Fusarium & avenascus & {$[13,17,21,32,47,90,93,106,122-125]$} \\
\hline & & dimerum & \\
\hline & & episphaeria & \\
\hline & & moniliforme & \\
\hline & & nivale & \\
\hline & & oxysporum & \\
\hline & & poae & \\
\hline & & solani & \\
\hline & & sporotrichioides & \\
\hline & & subglutinans & \\
\hline & & verticilloides & \\
\hline & Fusidium & terricola & [106] \\
\hline & Fusoma & - & {$[13]$} \\
\hline & Gibberalla & fuzikuroi & [106] \\
\hline & Moniliaceae & - & [122] \\
\hline & Volutella & - & {$[17,111]$} \\
\hline Niessliaceae & Stachybotrys & - & {$[13]$} \\
\hline Ophiostomatales & Sporothrix & schenckii & {$[100]$} \\
\hline Onygenaceae & Chrysosporium & - & [107] \\
\hline Orbiliaceae & Arthrobotrys & oligospora & [126] \\
\hline
\end{tabular}




\begin{tabular}{|c|c|c|c|}
\hline Family & Genus & Species & References \\
\hline Phycomycetaceae & Periconia & Keratidis & {$[106]$} \\
\hline Plectosphaerellaceae & Verticillium & - & [78] \\
\hline \multirow[t]{19}{*}{ Pleosporaceae } & Alternaria & alternata & {$[127]$} \\
\hline & Bipolaris & australiensis & \multirow[t]{3}{*}[33,83,127]{} \\
\hline & & hawaiiensis & \\
\hline & & spicefera & \\
\hline & Brachysporium & - & {$[78]$} \\
\hline & Curvularia & brachyspora & {$[115,121,127-135]$} \\
\hline & & fallax & \\
\hline & & geniculata & \\
\hline & & lunata & \\
\hline & & pallescens & \\
\hline & & prasadii & \\
\hline & & senegalensis & \\
\hline & & verruculosa & \\
\hline & Dreschlera & halodes & {$[82,115]$} \\
\hline & \multirow[t]{3}{*}{ Exserohilum (Setosphaeria) } & roseum & {$[83,89,117,125]$} \\
\hline & & rostratum & \\
\hline & & solani & \\
\hline & Helminthosporium & - & {$[78,82]$} \\
\hline & Stemphylium & - & {$[13]$} \\
\hline Pyllachoraceae & Colleotrichum & atramentum & {$[111]$} \\
\hline Pythiaceae & Pythium & insidiosum & {$[101,112]$} \\
\hline \multirow[t]{10}{*}{$\overline{\text { Saccharomycetaceae }}$} & \multirow[t]{9}{*}{ Candida ${ }^{2}$. } & albicans & \multirow[t]{9}{*}[21,24,47,49,88,113,116,125,136-139]{} \\
\hline & & curvata & \\
\hline & & humicola & \\
\hline & & glabrata & \\
\hline & & guilliermondii & \\
\hline & & lipolytica & \\
\hline & & parapsilosis & \\
\hline & & tropicalis & \\
\hline & & zeylanoides & \\
\hline & Saccharomyces & - & {$[13,109]$} \\
\hline Sclerotiniaceae & Botrytis & - & {$[106]$} \\
\hline Sordariaceae & Chrysonilia & sitophila & {$[101]$} \\
\hline \multirow[t]{2}{*}{ Sporidiobolaceae } & \multirow[t]{2}{*}{ Rhodotorula } & glutinis & \multirow[t]{2}{*}[140,141]{} \\
\hline & & minuta & \\
\hline Syncephalastraceae & Syncephalastrom & - & {$[82]$} \\
\hline \multirow[t]{2}{*}{ Tremellaceae } & \multirow[t]{2}{*}{ Cryptococcus } & laurentii & \multirow[t]{2}{*}[18,24,116]{} \\
\hline & & neoformans & \\
\hline
\end{tabular}




\begin{tabular}{|c|c|c|c|}
\hline Family & Genus & Species & References \\
\hline \multirow[t]{15}{*}{ Trichocomaceae } & \multirow[t]{9}{*}{ Aspergillus } & alternata & \multirow{9}{*}{$\begin{array}{c}{[13,83,91,94,110,122,123,125,128,130} \\
138,142]\end{array}$} \\
\hline & & flavus & \\
\hline & & fumigatus & \\
\hline & & glaucus & \\
\hline & & nidulans & \\
\hline & & niger & \\
\hline & & oryzae & \\
\hline & & terreus & \\
\hline & & versicolour & \\
\hline & \multirow[t]{4}{*}{ Penicillium } & citrinum & \multirow[t]{4}{*}[32,106,143]{} \\
\hline & & crustaceum & \\
\hline & & expansum & \\
\hline & & spinulosum & \\
\hline & \multirow[t]{2}{*}{ Paecilomyces } & farinosus & \multirow[t]{2}{*}[113,144,145]{} \\
\hline & & lilacinus & \\
\hline Trichosphaeriaceae & Khuskia & - & {$[90]$} \\
\hline \multirow[t]{3}{*}{ Trichosporonaceae } & \multirow[t]{3}{*}{ Trichosporon } & beigelii & \multirow[t]{3}{*}[90,95,106,140]{} \\
\hline & & capitatum & \\
\hline & & rugosum & \\
\hline Venturiaceae & Fusicladium & - & [13] \\
\hline \multirow[t]{3}{*}{$n / a$} & Cephaliophora & - & {$[13]$} \\
\hline & Dichotomophthoropsis & - & {$[90,146]$} \\
\hline & Mycelia & sterilia & {$[13,88,109]$} \\
\hline
\end{tabular}

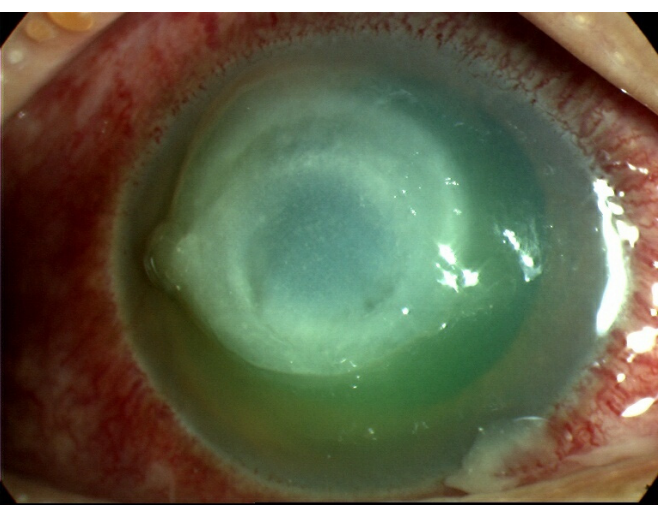

Fig. (3). Bacterial keratitis due to Pseudomonas spp.

\section{Amoebic Keratitis}

Acanthamoeba is a ubiquitous protozoan that can be largely found in soil and water in two stages of its lifecycle, the trophozoite (proliferative) stage or cyst stage [48]. Amoebic keratitis is closely associated with contact lens wear, with approximately $83 \%$ of cases occurring in lens users. In non-lens wearers it is usually a consequence of ocular trauma and exposure to contaminated water or soil, often in agricultural workers [51]. Amoebic keratitis has also been reported after surgical trauma including penetrating keratoplasty $(\mathrm{PK})$ and radial keratotomy (RK) procedures [51].

Acanthamoeba are capable of causing permanent visual impairment if not diagnosed and treated quickly [49, 50]. Diagnosed early, treatment with anti-amoebic therapy is generally successful [51]. A poor prognosis is associated with a delay in diagnosis [51]. While the commonly termed Acanthamoeba is the most studied agent of this type in keratitis, it is not the only amoebic infection that has been identified. Members of Vahlkampfia [52], Paravahlkampfia [53] and Hartmannella [54] species have also been identified in cases of amoebic keratitis (Table 5).

While treatment generally is successful, in unfavourable conditions Acanthamoeba have been known to invade and produce cysts that prolong their life-span. They have been shown to remain dormant for up to a year, before activation occurs, and they return to being trophozoites [49]. Further, topical steroids given to reduce inflammation have been shown to cause encystment and even promote amoebic proliferation [55].

The most common treatment for amoebic keratitis is chlorhexidine or combination therapy using polyhexamethylene biguanide (PHMB) and a diamadine such as 
Table 4. Diversity of Bacterial Species Implicated in Keratitis, (- Species Not Identified)

\begin{tabular}{|c|c|c|c|}
\hline Family & Genus & Species & References \\
\hline Actinomycetaceae & Actinomyces & bovis & [106] \\
\hline \multirow[t]{2}{*}{ Alcaligenaceae } & Achromobacter & - & {$[10,147]$} \\
\hline & Alcaligenes & faecalis & {$[40,148]$} \\
\hline Bacillaceae & Bacillus & subtilis & {$[130,149]$} \\
\hline Burkholderiaceae & Burkholderia & cepacia & {$[94,150]$} \\
\hline \multirow[t]{2}{*}{ Clostridiaceae } & Peptostreptococcus & micros & [131] \\
\hline & Sarcina & - & [111] \\
\hline \multirow{3}{*}{ Corynebacteriaceae } & \multirow{3}{*}{ Corynebacterium } & minutissimum & \multirow{3}{*}[14,91,92,130,151]{} \\
\hline & & pyogenes & \\
\hline & & xerosis & \\
\hline \multirow[t]{11}{*}{ Enterobacteriaceae } & Citrobacter & diversus & \multirow[t]{2}{*}[47,152]{} \\
\hline & & freundic & \\
\hline & Enterobacter & aerogenes & \multirow[t]{2}{*}[37,138,140,152]{} \\
\hline & & cloacae & \\
\hline & Escherichia & coli & {$[108,151]$} \\
\hline & Pantoea & agglomerans & {$[96]$} \\
\hline & Proteus & mirabilis & {$[108,152,153]$} \\
\hline & & vulgaris & \\
\hline & Providencia & - & [113] \\
\hline & Serratia & liguefaciens & {$[34,40,124,151]$} \\
\hline & & marcescens & \\
\hline Enterococcaceae & Enterococcus & faecalis & {$[93,138]$} \\
\hline \multirow[t]{3}{*}{ Flavobacteriaceae } & Capnocytophaga & - & {$[154]$} \\
\hline & Flavobacterium & meningosepticum & [94] \\
\hline & Chryseoacterium & - & [113] \\
\hline Micrococcaceae & Micrococcus & - & {$[83,135]$} \\
\hline \multirow[t]{4}{*}{ Moraxellaceae } & \multirow[t]{2}{*}{ Acinetobacter } & baumannii & \multirow[t]{2}{*}[37,94,135,140]{} \\
\hline & & calcoaceticus & \\
\hline & \multirow[t]{2}{*}{ Moraxella } & catarrhalis & \multirow[t]{2}{*}[34,79,130,147]{} \\
\hline & & launata & \\
\hline
\end{tabular}




\begin{tabular}{|c|c|c|c|}
\hline Family & Genus & Species & References \\
\hline \multirow[t]{3}{*}{ Mycobacteriaceae } & \multirow[t]{3}{*}{ Mycobacteria } & abscessus & \multirow[t]{3}{*}[10,94,113]{} \\
\hline & & chelinae & \\
\hline & & fotuitum & \\
\hline \multirow[t]{4}{*}{ Neisseriaceae } & Eikenella & corrodens & {$[10]$} \\
\hline & Kingella & denitrificans & [10] \\
\hline & \multirow[t]{2}{*}{ Neisseria } & gonorrhoea & \multirow[t]{2}{*}[113,123,152]{} \\
\hline & & meningitides & \\
\hline Nocardiaceae & Nocardia & asteroides & {$[152,155]$} \\
\hline \multirow[t]{3}{*}{ Pasteurellaceae } & \multirow[t]{3}{*}{ Haemophilus } & aegyticus & \multirow[t]{3}{*}[124,152,156]{} \\
\hline & & influenza & \\
\hline & & parainfluenza & \\
\hline Peptococcaceae & Peptococcus & prevotii & {$[14,91]$} \\
\hline Propionibacteriaceae & Propionibacterium & acnes & {$[2,94]$} \\
\hline \multirow[t]{6}{*}{ Pseudomonadaceae } & \multirow[t]{6}{*}{ Pseudomonas } & acidovorans & \multirow[t]{6}{*}[14,34,79,138,140,146,147]{} \\
\hline & & aeruginosa & \\
\hline & & cepacia & \\
\hline & & fluorescens & \\
\hline & & maltphilia & \\
\hline & & oryzihabitans & \\
\hline \multirow[t]{3}{*}{ Staphylococcaceae } & \multirow[t]{3}{*}{ Staphylococcus } & aureus & \multirow[t]{3}{*}[40,93,108,148]{} \\
\hline & & epidermidis & \\
\hline & & coagulase negative & \\
\hline \multirow[t]{9}{*}{ Streptococcaceae } & \multirow[t]{9}{*}{ Streptococcus } & dysgalactie & \multirow[t]{9}{*}[10,34,40,93,94,96,131,135,140,157]{} \\
\hline & & mitis & \\
\hline & & morbillorum & \\
\hline & & oralis & \\
\hline & & parasanguis & \\
\hline & & pyogenes & \\
\hline & & salivarius & \\
\hline & & sanguinis & \\
\hline & & viridans & \\
\hline Streptomycetaceae & Streptomyces & - & [104] \\
\hline Vibrionaceae & Vibrio & vulnificus & {$[158,159]$} \\
\hline \multirow[t]{2}{*}{ Xanthomonadaceae } & Stenotrophomonas & maltophilia & {$[37,140,150,151]$} \\
\hline & Xanthomonas & - & [157] \\
\hline
\end{tabular}

propamidine isethionate [56]. Kosrirukvongs et al. [56] compared the efficacy of these treatments and reported that the use of such combination therapy resulted in better visual acuity for the patients. Narasimhan et al. [57] showed that the use of PHMB was more successful against trophozoites in vitro. Diamidines have been shown to be successful against both the trophozoite and cyst forms [51].
Acanthamoebic keratitis is most commonly identified in its early stages by dendritiform epithelial pattern, small white infiltrates and radial keratoneuritis. Fig. (4) shows epithelial irregularity in early acanthamoeba keratitis [58, 59]. As the infection progresses, it can take up to 3 months for the classic ring-shaped cellular infiltrate to form, however this indication is unreliable for early instigation of treatment [60]. Corneal suppuration, abscess formation, 
Table 5. List of Microorganisms Identified as the Infectious Agent in Conditions of Amoebic Keratitis, (- Species Not Identified)

\begin{tabular}{|c|c|c|c|}
\hline Family & Genus & Species & References \\
\hline \multirow[t]{6}{*}{ Acanthamoebidae } & \multirow[t]{6}{*}{ Acanthamoeba } & casellanii & \multirow[t]{6}{*}{$49,56,160-162$} \\
\hline & & hatchetti & \\
\hline & & lugdunesis & \\
\hline & & mauritaniensis & \\
\hline & & polyphaga & \\
\hline & & rhysodes & \\
\hline Hartmannellidae & Hatmanella & vermiformis & {$[54]$} \\
\hline \multirow[t]{2}{*}{ Valkampfiidae } & \multirow{2}{*}{$\begin{array}{c}\text { Vahlkampfia } \\
\text { Paravahlkampfia }\end{array}$} & - & {$[52,163]$} \\
\hline & & - & {$[53]$} \\
\hline
\end{tabular}

chorioretinitis and chronic immune-mediated scleritis have been reported with the progression of acanthamoebic keratitis [49].

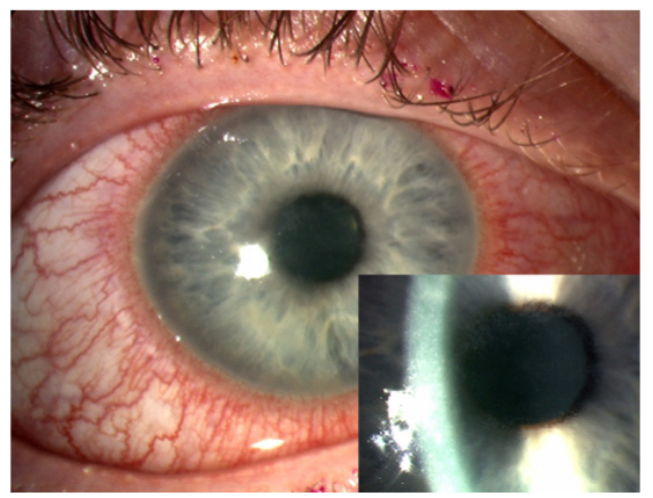

Fig. (4). Acanthamoeba keratitis, Insert: higher magnification showing epithelial irregularity in early acanthamoeba keratitis.

\section{Viral Keratitis}

Herpes Simplex Virus keratitis is the most common cause of irreversible blindness in developed countries. Worldwide, an estimated 10 million persons suffer from herpetic keratitis, with about 2 million individuals left with impaired vision [61-63]. Although Herpes Simplex VirusType 1 (HSV-1) is the most common cause of viral keratitis, it is not the only implicated viral pathogen. Varicella Zoster Virus, also a member of the Herpes viridae family, has been identified as a causal agent in a select few cases, while the Vaccinia virus has been identified as the result of an adverse reaction to the small pox immunisation (Table 6) [64-66].

With a seroprevalence of HSV-1 as high as $76 \%$, the Herpetic Eye Disease Study (HEDS) found a recurrence rate of approximately $34 \%$ [67, 68]. HSV are reported to frequently reside within neural cells, where they can become latent [69]. Clinically, it has been suggested that the dendritic patterns common in HSV-1 keratitis mirror the patterns of the subbasal nerve plexus present in the corneal epithelium [70], indicating the migration of the virus into neural cells. Latency in neural crest cells is thought to explain the high incidence recurrence.

Primary HSV keratitis is clinically characterised by a dendritic lesion which has a morphological branching pattern across the cornea [71]. Recurrent disease is characterised by followed by corneal scarring, thinning, and vascularisation [72] (Fig. 5). The early stages of HSV-1 infection closely correspond to the clinical presentation of Acanthamoebic keratitis.

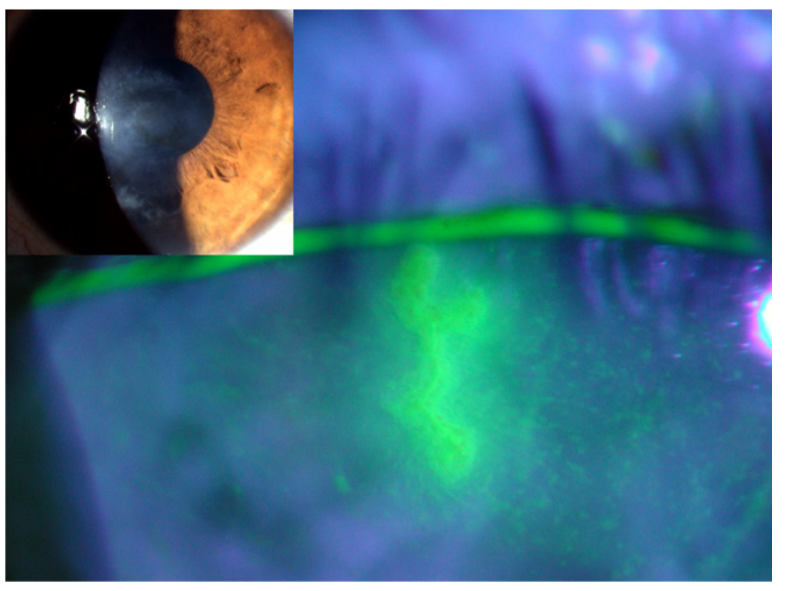

Fig. (5). A dendritic ulcer from herpes simplex keratitis stained with fluorescein and viewed with a cobalt blue light. Insert: appearance in natural light.

Table 6. List of Microorganisms Identified as the Infectious Agents in Conditions of Viral Keratitis

\begin{tabular}{|c|c|c|c|}
\hline Family & Genus & Species & References \\
\hline \hline Herpesviridae & Varicellovirus & Varicella Zoster Virus & {$[64,65,73]$} \\
& Simplexvirus & Herpes Simplex Virus- 1 & {$[164,165]$} \\
\hline Paramyxoviridae & Morbillivirus & Rubeola virus & {$[166]$} \\
\hline Poxviridae & Orthopoxvirus & Vaccinia Virus & \\
\hline
\end{tabular}


Table 7. Summary of the Most Common Risk Factors Associated with Keratitis

\begin{tabular}{|c|c|c|}
\hline Risk Factors & Commonly Associated Microorganisms & References \\
\hline \hline Ocular Trauma & Fungal, i.e. Fusarium spp & {$[11,83]$} \\
\hline Use of Contact Lenses & Bacterial, i.e. Pseudomonas aeruginosa & {$[34,78]$} \\
\hline Ocular Surface Disease & Yeast infections, i.e. Candida albicans & {$[18]$} \\
\hline Systemic Disease & Opportunistic organisms & {$[86,87,167]$} \\
\hline Use of Corticosteroids & All & {$[87$} \\
\hline
\end{tabular}

Acyclovir is the accepted primary treatment for herpetic keratitis. Acyclovir is a deoxyguanosine analogue, and postphosphorylation it is a potent inhibitor of viral DNA polymerase; however, there are reports of growing resistance to acyclovir [73]. Resistance to deoxyguanosine analogues can develop through mutation of the viral gene thymidine kinase, which is essential for the phosphorylation of acyclovir. However, not all prescribed medication requires thymidine kinase for activity and consequently resistance is mostly acyclovir specific. In contrast, resistance that arises through mutation of the viral DNA polymerase can influences a wide range of anti-viral drugs [73, 74]. Wilhelmus [63] has conducted an extensive review on the quality and efficacy of the currently prescribed anti-viral topical treatments $[63,75]$. Corneal graft surgery in patients with HSK has been associated with recurrence of infection and is often avoided unless needed to manage a corneal perforation [76].

\section{Keratitis Risk Factors}

Microbial keratitis usually occurs in conjunction with specific risk factors [77]. The most common of which are the use of contact lenses, corneal trauma, or underlying ocular surface disease (Table 7). Recent work by Shah et al. suggests statistically significant relationships between gross national income and fungal or bacterial keratitis with the former more prevalent in developing nations [6].

The use of contact lenses has been closely associated with an increased incidence of bacterial keratitis [34]. Pseudomonas aeruginosa and Staphylococcal species are some of the most common organisms cultured in contact lens associated bacterial keratitis [78]. Development of hydrogel day and night wear contact lenses coupled with greater comfort, leading to longer wearing times, and fashion trends for coloured contact lenses without refractive correction, saw an increase in contact lens use and misuse, with an initial increase in ocular infections [79]. A recent study by Stapleton and coworkers indicated that overnight wear of contact lenses, despite the introduction of silicone hydrogel materials that decrease hypoxia compared to hydrogel lens types, still has an increased incidence of infection compared to daily wear [124]. Contact lenses can serve as a platform for the microbial proliferation, encouraging microbial adhesion to the cornea. Korb et al. [77] have suggested that the use of contact lenses can also interfere with the ocular defences, by leading to hypoxia and/or disruption of the epithelial-tear film interactions, a view supported by others such as McNarma et al. [80] and Thakur and Wilcox [81].
Direct corneal damage disrupts the innate immune system of the eye, enabling entry by microbes into the abrasion and consequent infection. Trauma is quite commonly associated with infection by filamentous fungi such as Fusarium solani, Aspergillus spp and Bipolaris spp; especially when the trauma is caused by vegetative matter particularly in tropical climates $[82,83]$. It is most likely that the vegetative material was previously colonised by the microorganisms, and consequently injury and infection occurs almost simultaneously [11].

Corneal surgery is a risk factor for microbial keratitis as the corneal epithelial barrier is breached [11]. Due to the immune-privileged nature of the eye, any break in the corneal epithelium renders the eye susceptible to infection. Furthermore, post-operative care usually requires the use of topical steroids to control the immune response. The prophylactic use of corticosteroids has become quite controversial and has been associated with an increase in microbial growth and keratitis [84]. A number of reports have suggested that corticosteroids may either facilitate an increase in microbial proliferation and/or possibly impair the ocular immune response thus encouraging microbial infection [85-87].

Local weakening of the immune defences is the most common predisposing factor associated with keratitis caused by opportunistic infections, such as by Candida albicans or other yeast fungi [18]. In contrast, systemic immune systems affected by diseases such as diabetes mellitus and HIV infection are associated with a great range of opportunistic infections [88]. It is also possible for keratitis to develop as a result of endogenous infections, typically by Gram positive bacteria such as Staphylococcus spp. [5].

\section{CONCLUSIONS}

Keratitis is a serious infection of the eye and contributes to one of the leading causes of monocular blindness worldwide. Whilst statistics are difficult to obtain, there is evidence of regional variability in both incidence and type of infection [5, 58, 89-96]. For example, contact lens related bacterial keratitis is more prevalent in developed countries whereas fungal keratitis is a major blinding disease in more tropical climates [27, 97, 98].

This review has revealed 232 species reported to be infectious agents in keratitis and can act as a resource to clinicians and researchers for initial information on species. However, identification of species associated with microbial keratitis is relatively complex; [10] microbiological sampling does not always yield a result and different micro-organisms 
can produce a similar clinical picture [11,60]. Furthermore, few clinical signs are pathgnonomic for the type of infection; for example: perineural infiltrates are virtually pathgnomonic for Acanthamoeba infection [51] however they have also been reported in bacterial keratitis [99]. Thus, improved diagnostic techniques, such as polymerase chain reaction (PCR), are clearly needed for routine use in cases of microbial keratitis to rapidly identify the infectious agent and permitting targeted therapy.

Current treatment for microbial keratitis involves an intensive regime of topical therapy, with significant morbidity and inconvenience for the patient, such that treatments available for microbial keratitis need to be improved [32, 37, 98]. However, despite previous efforts in designing solid drug delivery systems, the most popular and accepted forms of antibiotics for local delivery remain as liquid or gel forms for topical administration. In the eye, antibiotics delivered as eye drops suffer rapid and extensive pre-corneal loss caused by drainage and high tear turnover; typically less than $5 \%$ of applied drug penetrates the cornea and reaches intra-ocular tissues [8]; thus, appropriate dosing is difficult [100]. Furthermore, there is a distinct lack of information concerning the pathogenesis of how the different types of microbial keratitis develop and the host factor involved. Advances in our knowledge of keratitis, in particular data on the causal organisms, will facilitate the development of more specific and effective treatments as well as techniques to prevent infection.

\section{CONFLICT OF INTEREST}

The authors confirm that this article content has no conflict of interest.

\section{ACKNOWLEDGEMENTS}

The authors acknowledge the support of grants from the Ophthalmic Research Institute of Australia (ORIA) and the National Health and Medical Research Council (NHMRC, APP630510) to Foster and Watson.

\section{REFERENCES}

[1] Shukla PK, Kumar M, Keshava GB. Mycotic keratitis: an overview of diagnosis and therapy. Mycoses 2008; 51(3): 183-99.

[2] Keay L, Edwards K, Naduvilath T, et al. Microbial keratitis predisposing factors and morbidity. Ophthalmology 2006; 113(1): 109-16.

[3] Liesegang TJ. Contact lens-related microbial keratitis: part i: epidemiology. Cornea 1997; 16(2): 125-31.

[4] Whitcher JP, Srinivasan M, Upadhyay MP. Corneal blindness: a global perspective. Bull World Health Organ 2001; 79(3): 214-21.

[5] Stapleton F, Keay LJ, Sanfilippo PG, Katiyar S, Edwards KP, Naduvilath T. Relationship between climate, disease severity, and causative organism for contact lens-associated microbial keratitis in Australia. Am J Ophthalmol 2007; 144(5): 690-8.

[6] Shah A, Sachdev A, Coggon D, Hossain P. Geographic variations in microbial keratitis: an analysis of the peer-reviewed literature. $\mathrm{Br}$ J Ophthalmol 2011; 95(6): 762-7.

[7] Asbell PA, Colby KA, Deng S, et al. Ocular TRUST: nationwide antimicrobial susceptibility patterns in ocular isolates. Am J Ophthalmol 2008; 145(6): 951-8.

[8] Alonso MJ, Sanchez A. The potential of chitosan in ocular drug delivery. J Pharm Pharmacol 2003; 55(11): 1451-63.

[9] Thomas PA. Mycotic keratitis--an underestimated mycosis. J Med Vet Mycol 1994; 32(4): 235-56.
[10] Dahlgren MA, Lingappan A, Wilhelmus KR. The clinical diagnosis of microbial keratitis. Am J Ophthalmol 2007; 143(6): 940-4.

[11] Thomas PA. Fungal infections of the cornea. Eye 2003; 17(8): 85262.

[12] Sun RL, Jones DB, Wilhelmus KR. Clinical characteristics and outcome of Candida keratitis. Am J Ophthalmol 2007; 143(6): 1043-5.

[13] Wang L, Sun S, Jing Y, Han L, Zhang H, Yue J. Spectrum of fungal keratitis in central China. Clin Experiment Ophthalmol 2009; 37(8): 763-71.

[14] Seal DV, Kirkness CM, Bennett HG, Peterson M. Population-based cohort study of microbial keratitis in Scotland: incidence and features. Cont Lens Anterior Eye 1999; 22(2): 49-57.

[15] Rautaraya B, Sharma S, Kar S, Das S, Sahu SK. Diagnosis and treatment outcome of mycotic keratitis at a tertiary eye care center in eastern India. BMC Ophthalmol 2011, 11:39.

[16] Garg P, Gopinathan U, Choudhary K, Rao GN. Keratomycosis: clinical and microbiologic experience with dematiaceous fungi. Ophthalmology 2000; 107(3): 574-80.

[17] Forster RK, Rebell G. Therapeutic surgery in failures of medical treatment for fungal keratitis. Br J Ophthalmol 1975; 59(7): 36671.

[18] Tanure MA, Cohen EJ, Sudesh S, Rapuano CJ, Laibson PR. Spectrum of fungal keratitis at Wills Eye Hospital, Philadelphia, Pennsylvania. Cornea 2000; 19(3): 307-12.

[19] O'Day DM. Selection of appropriate antifungal therapy. Cornea 1987; 6(4): 238-45.

[20] Lalitha P, Prajna NV, Kabra A, Mahadevan K, Srinivasan M. Risk factors for treatment outcome in fungal keratitis. Ophthalmology 2006; 113(4): 526-30.

[21] Galarreta DJ, Tuft SJ, Ramsay A, Dart JK. Fungal keratitis in London: microbiological and clinical evaluation. Cornea 2007; 26(9): 1082-6.

[22] Yilmaz S, Maden A. Severe fungal keratitis treated with subconjunctival fluconazole. Am J Ophthalmol 2005; 140(3): 4548.

[23] Prajna NV, Mascarenhas J, Krishnan T, et al. Comparison of natamycin and voriconazole for the treatment of fungal keratitis. Arch Ophthalmol 2010; 128(6): 672-8.

[24] Ritterband DC, Seedor JA, Shah MK, Koplin RS, McCormick SA. Fungal keratitis at the new york eye and ear infirmary. Cornea 2006; 25(3): 264-7.

[25] Kalavathy CM, Parmar P, Kaliamurthy J, et al. Comparison of topical itraconazole $1 \%$ with topical natamycin $5 \%$ for the treatment of filamentous fungal keratitis. Cornea 2005; 24(4): 44952.

[26] Manzouri B, Vafidis GC, Wyse RK. Pharmacotherapy of fungal eye infections. Expert Opin Pharmacother 2001; 2(11): 1849-57.

[27] Sengupta S, Rajan S, Reddy PR, et al. Comparative study on the incidence and outcomes of pigmented versus non pigmented keratomycosis. Indian J Ophthalmol 2011; 59(4): 291-6.

[28] Kaur IP, Kakkar S. Topical delivery of antifungal agents. Expert Opin Drug Deliv 2010; 7(11): 1303-27.

[29] Mahdy RA, Nada WM, Wageh MM, Kader MA, Saleh MM, Alswad MM. Assessment safety and efficacy of a combination therapy of topical amphotericin B and subconjunctival fluconazole for the treatment of fungal keratitis. Cutan Ocul Toxicol 2010; 29(3): 193-7.

[30] Shah KB, Wu TG, Wilhelmus KR, Jones DB. Activity of voriconazole against corneal isolates of Scedosporium apiospermum. Cornea 2003; 22(1): 33-6.

[31] Ozbek Z, Kang S, Sivalingam J, Rapuano CJ, Cohen EJ, Hammersmith KM. Voriconazole in the management of Alternaria keratitis. Cornea 2006; 25(2): 242-4.

[32] Xie L, Zhong W, Shi W, Sun S. Spectrum of fungal keratitis in north China. Ophthalmology 2006; 113(11): 1943-8.

[33] Saha R, Das S. Mycological profile of infectious Keratitis from Delhi. Indian J Med Res 2006; 123(2): 159-64.

[34] Bourcier T, Thomas F, Borderie V, Chaumeil C, Laroche L. Bacterial keratitis: predisposing factors, clinical and microbiological review of 300 cases. Br J Ophthalmol 2003; 87(7): 834-8.

[35] Titiyal JS, Negi S, Anand A, Tandon R, Sharma N, Vajpayee RB. Risk factors for perforation in microbial corneal ulcers in north India. Br J Ophthalmol 2006; 90(6): 686-9. 
[36] Hazlett LD. Corneal response to Pseudomonas aeruginosa infection. Prog Retin Eye Res 2004; 23(1): 1-30.

[37] Kaye S, Tuft S, Neal T, et al. Bacterial susceptibility to topical antimicrobials and clinical outcome in bacterial keratitis. Invest Ophthalmol Vis Sci 2010; 51(1): 362-8.

[38] Hobden JA, Engel LS, Callegan MC, Hill JM, Gebhardt BM, O'Callaghan RJ. Pseudomonas aeruginosa keratitis in leukopenic rabbits. Curr Eye Res 1993; 12(5): 461-7.

[39] Bower KS, Kowalski RP, Gordon YJ. Fluoroquinolones in the treatment of bacterial keratitis. Am J Ophthalmol 1996; 121(6): $712-5$.

[40] Schaefer F, Bruttin O, Zografos L, Guex-Crosier Y. Bacterial keratitis: a prospective clinical and microbiological study. Br J Ophthalmol 2001; 85(7): 842-7.

[41] Jhanji V, Sharma N, Satpathy G, Titiyal J. Fourth-generation fluoroquinolone-resistant bacterial keratitis. J Cataract Refract Surg 2007; 33(8): 1488-9.

[42] Shalchi Z, Gurbaxani A, Baker M, Nash J. Antibiotic resistance in microbial keratitis: ten-year experience of corneal scrapes in the United kingdom. Ophthalmology 2011; 118(11): 2161-5.

[43] Reviglio VE, Hakim MA, Song JK, O'Brien TP. Effect of topical fluoroquinolones on the expression of matrix metalloproteinases in the cornea. BMC Ophthalmol 2003; 3: 10.

[44] McLeod SD, LaBree LD, Tayyanipour R, Flowers CW, Lee PP, McDonnell PJ. The importance of initial management in the treatment of severe infectious corneal ulcers. Ophthalmology 1995; 102(12): 1943-8.

[45] Lorian V, Burns L. Predictive value of susceptibility tests for the outcome of antibacterial therapy. J Antimicrob Chemother 1990; 25(1): 175-81.

[46] Foster LJ, Thomson K, Marcal H, Butt J, Watson SL, Wakefield D. Chitosan-vancomysin composite biomaterial as a laser activated surgical adhesive with regional antimicrobial activity. Biomacromolecules 2010; 11(12): 3563-70.

[47] Tuft SJ, Tullo AB. Fungal keratitis in the United Kingdom 20032005. Eye 2009; 23(6): 1308-13.

[48] da Rocha-Azevedo B, Tanowitz HB, Marciano-Cabral F. Diagnosis of infections caused by pathogenic free-living amoebae. Interdiscip Perspect Infect Dis 2009; 2009: 251406.

[49] Naginton J, Watson PG, Playfair TJ, McGill J, Jones BR, Steele AD. Amoebic infection of the eye. Lancet 1974; 2(7896): 1537-40.

[50] Schuster FL, Visvesvara GS. Free-living amoebae as opportunistic and non-opportunistic pathogens of humans and animals. Int $\mathbf{J}$ Parasitol 2004; 34(9): 1001-27.

[51] Dart JK, Saw VP, Kilvington S. Acanthamoeba keratitis: diagnosis and treatment update 2009. Am J Ophthalmol 2009; 148(4): 487499 e 482.

[52] Bennett HG, Hay J, Kirkness CM, Seal DV, Devonshire P. Antimicrobial management of presumed microbial keratitis: guidelines for treatment of central and peripheral ulcers. $\mathrm{Br} \mathrm{J}$ Ophthalmol 1998; 82(2): 137-45.

[53] Ozkoc S, Tuncay S, Delibas SB, et al. Identification of Acanthamoeba genotype T4 and Paravahlkampfia sp. from two clinical samples. J Med Microbiol 2008; 57(Pt 3): 392-6.

[54] Kennedy SM, Devine P, Hurley C, Ooi YS, Collum LM. Corneal infection associated with Hartmannella vermiformis in contact-lens wearer. Lancet 1995; 346(8975): 637-8.

[55] Berger ST, Mondino BJ, Hoft RH, et al. Successful medical management of Acanthamoeba keratitis. Am J Ophthalmol 1990; 110(4): 395-403.

[56] Kosrirukvongs P, Wanachiwanawin D, Visvesvara GS. Treatment of acanthamoeba keratitis with chlorhexidine. Ophthalmology 1999; 106(4): 798-802.

[57] Narasimhan S, Madhavan HN, Ka LT. Development and application of an in vitro susceptibility test for Acanthamoeba species isolated from keratitis to polyhexamethylene biguanide and chlorhexidine. Cornea 2002; 21(2): 203-5.

[58] Moore MB, McCulley JP, Kaufman HE, Robin JB. Radial keratoneuritis as a presenting sign in Acanthamoeba keratitis. Ophthalmology 1986; 93(10): 1310-15.

[59] Mutoh T, Ishikawa I, Matsumoto Y, Chikuda M: A retrospective study of nine cases of Acanthamoeba keratitis. Clin Ophthalmol 2010; 4: 1189-92.

[60] Bacon AS, Dart JK, Ficker LA, Matheson MM, Wright P. Acanthamoeba keratitis. The value of early diagnosis. Ophthalmology 1993; 100(8): 1238-43.
[61] Liesegang TJ. Herpes simplex virus epidemiology and ocular importance. Cornea 2001; 20(1): 1-13.

[62] Knickelbein JE, Hendricks RL, Charukamnoetkanok P. Management of herpes simplex virus stromal keratitis: an evidencebased review. Surv Ophthalmol 2009; 54(2): 226-34.

[63] Wilhelmus KR. Antiviral treatment and other therapeutic interventions for herpes simplex virus epithelial keratitis. Cochrane Database Syst Rev 2010(12):CD002898.

[64] Pavan-Langston D, McCulley JP. Herpes zoster dendritic keratitis. Arch Ophthalmol 1973; 89(1): 25-9.

[65] Kandori M, Inoue T, Takamatsu F, Hori Y, Maeda N, Tano Y. Two cases of Varicella zoster virus keratitis with atypical extensive pseudodendrites. Jpn J Ophthalmol 2009; 53(5): 548-9.

[66] Pepose JS, Margolis TP, LaRussa P, Pavan-Langston D. Ocular complications of smallpox vaccination. Am J Ophthalmol 2003; 136(2): 343-52.

[67] Cunningham AL, Taylor R, Taylor J, Marks C, Shaw J, Mindel A. Prevalence of infection with herpes simplex virus types 1 and 2 in Australia: a nationwide population based survey. Sex Transm Infect 2006; 82(2): 164-8.

[68] Group HEDS. Acyclovir for the prevention of recurrent herpes simplex virus eye disease. Herpetic Eye Disease Study Group. N Engl J Med 1998; 339(5): 300-6.

[69] Lilley CE, Carson CT, Muotri AR, Gage FH, Weitzman MD: DNA repair proteins affect the lifecycle of herpes simplex virus 1 . Proc Natl Acad Sci USA 2005; 102(16): 5844-9.

[70] Remeijer L, Osterhaus A, Verjans G. Human herpes simplex virus keratitis: the pathogenesis revisited. Ocul Immunol Inflamm 2004; 12(4): 255-85.

[71] Kaye S, Choudhary A. Herpes simplex keratitis. Prog Retin Eye Res 2006; 25(4): 355-80.

[72] Dana MR, Streilein JW. Loss and restoration of immune privilege in eyes with corneal neovascularization. Invest Ophthalmol Vis Sci 1996; 37(12): 2485-94.

[73] Choong K, Walker NJ, Apel AJ, Whitby M. Aciclovir-resistant herpes keratitis. Clin Exper Ophthalmol 2010; 38(3): 309-13.

[74] Gilbert C, Bestman-Smith J, Boivin G. Resistance of herpesviruses to antiviral drugs: clinical impacts and molecular mechanisms. Drug Resist Updat 2002; 5(2): 88-114

[75] Guess S, Stone DU, Chodosh J. Evidence-based treatment of herpes simplex virus keratitis: a systematic review. Ocul Surf 2007; 5(3): 240-50.

[76] Sterk CC, Jager MJ, Swart-vd Berg M. Recurrent herpetic keratitis in penetrating keratoplasty. Doc Ophthalmol 1995; 90(1): 29-33.

[77] Korb DR, Greiner JV, Glonek T. Tear film lipid layer formation implications for contact lens wear. Optom Vis Sci 1996; 73(3): 189-92.

[78] Ormerod LD, Smith RE. Contact lens-associated microbial keratitis. Arch Ophthalmol 1986; 104(1): 79-83.

[79] Dart JK, Stapleton F, Minassian D. Contact lenses and other risk factors in microbial keratitis. Lancet 1991; 338(8768): 650-3.

[80] McNamara NA, Fusaro RE, Brand RJ, Polse KA. Epithelial permeability reflects subclinical effects of contact lens wear. Br J Ophthalmol 1998; 82(4): 376-81.

[81] Thakur A, Willcox MD. Contact lens wear alters the production of certain inflammatory mediators in tears. Exp Eye Res 2000; 70(3): 255-29.

[82] Panda A, Sharma N, Das G, Kumar N, Satpathy G. Mycotic keratitis in children: epidemiologic and microbiologic evaluation. Cornea 1997; 16(3): 295-9.

[83] Leck AK, Thomas PA, Hagan M, et al. Aetiology of suppurative corneal ulcers in Ghana and south India, and epidemiology of fungal keratitis. Br J Ophthalmol 2002; 86(11): 1211-5.

[84] Watson SL. Supurative keratitis. In: Evidence-based ophthalmology. Wormald R, Smeeth L, Henshaw K, Shah A, Eds. London, UK: BMJ Books 2004

[85] McClellan KA. Mucosal defense of the outer eye. Surv Ophthalmol 1997; 42(3): 233-46.

[86] Stern GA, Buttross M. Use of corticosteroids in combination with antimicrobial drugs in the treatment of infectious corneal disease. Ophthalmology 1991; 98(6): 847-53.

[87] Srinivasan M, Lalitha P, Mahalakshmi R, et al. Corticosteroids for bacterial corneal ulcers. Br J Ophthalmol 2009; 93(2): 198-202.

[88] Bharathi MJ, Ramakrishnan R, Meenakshi R, Padmavathy S, Shivakumar C, Srinivasan M. Microbial keratitis in South India: 
influence of risk factors, climate, and geographical variation. Ophthalmic Epidemiol 2007; 14(2): 61-9.

[89] Laspina F, Samudio M, Cibils D, et al. Epidemiological characteristics of microbiological results on patients with infectious corneal ulcers: a 13-year survey in Paraguay. Graefes Arch Clin Exp Ophthalmol 2004; 242(3): 204-9.

[90] Hagan M, Wright E, Newman M, Dolin P, Johnson G. Causes of suppurative keratitis in Ghana. Br J Ophthalmol 1995; 79(11): 1024-8.

[91] Carmichael TR, Wolpert M, Koornhof HJ. Corneal ulceration at an urban African hospital. Br J Ophthalmol 1985; 69(12): 920-6.

[92] Basak SK, Basak S, Mohanta A, Bhowmick A. Epidemiological and microbiological diagnosis of suppurative keratitis in Gangetic West Bengal, eastern India. Indian J Ophthalmol 2005; 53(1): 1722.

[93] Houang E, Lam D, Fan D, Seal D. Microbial keratitis in Hong Kong: relationship to climate, environment and contact-lens disinfection. Trans R Soc Trop Med Hyg 2001; 95(4): 361-7.

[94] Fong CF, Tseng CH, Hu FR, Wang IJ, Chen WL, Hou YC. Clinical characteristics of microbial keratitis in a university hospital in Taiwan. Am J Ophthalmol 2004; 137(2): 329-36.

[95] Rosa RH, Jr, Miller D, Alfonso EC. The changing spectrum of fungal keratitis in south Florida. Ophthalmology 1994; 101(6): 1005-13.

[96] Ibrahim MM, Vanini R, Ibrahim FM, et al. Epidemiology and medical prediction of microbial keratitis in southeast Brazil. Arq Bras Oftalmol 2011; 74(1): 7-12.

[97] Young RC, Hodge DO, Liesegang TJ, Baratz KH. Incidence, recurrence, and outcomes of herpes simplex virus eye disease in Olmsted County, Minnesota, 1976-2007: the effect of oral antiviral prophylaxis. Arch Ophthalmol 2010; 128(9): 1178-83.

[98] Srinivasan M. Fungal keratitis. Curr Opin Ophthalmol 2004; 15(4): 321-7.

[99] Feist RM, Sugar J, Tessler H. Radial keratoneuritis in Pseudomonas keratitis. Arch Ophthalmol 1991; 109(6): 774-5.

[100] Lee VH, Robinson JR: Topical ocular drug delivery. recent developments and future challenges. J Ocul Pharmacol 1986; 2(1): 67-108.

[101] Sirikul T, Prabriputaloong T, Smathivat A, Chuck RS, Vongthongsri A. Predisposing factors and etiologic diagnosis of ulcerative keratitis. Cornea 2008; 27(3): 283-7.

[102] Balne PK, Nalamada S, Kodiganti M, Taneja M. Fungal keratitis caused by Chaetomium atrobrunneum. Cornea 2012; 31(1): 94-5.

[103] Kotigadde S, Ballal M, Jyothirlatha, Kumar A, Srinivasa R, Shivananda PG. Mycotic keratitis: a study in coastal Karnataka. Indian J Ophthalmol 1992; 40(1): 31-3.

[104] Poria VC, Bharad VR, Dongre DS, Kulkarni MV. Study of mycotic keratitis. Indian J Ophthalmol 1985; 33(4): 229-31.

[105] Kisla TA, Cu-Unjieng A, Sigler L, Sugar J. Medical management of Beauveria bassiana keratitis. Cornea 2000; 19(3): 405-6.

[106] Gingrich WD. Keratomycosis. JAMA 1962; 179: 602-8.

[107] Gopinathan U, Garg P, Fernandes M, Sharma S, Athmanathan S, Rao GN. The epidemiological features and laboratory results of fungal keratitis: a 10-year review at a referral eye care center in South India. Cornea 2002; 21(6): 555-9.

[108] Srinivasan M, Gonzales CA, George C, et al. Epidemiology and aetiological diagnosis of corneal ulceration in Madurai, south India. Br J Ophthalmol 1997; 81(11): 965-71.

[109] Xuguang S, Zhixin W, Zhiqun W, Shiyun L, Ran L. Ocular fungal isolates and antifungal susceptibility in northern China. Am J Ophthalmol 2007; 143(1): 131-3.

[110] Chander J, Sharma A. Prevalence of fungal corneal ulcers in northern India. Infection 1994; 22(3): 207-9.

[111] Liesegang TJ, Forster RK. Spectrum of microbial keratitis in South Florida. Am J Ophthalmol 1980; 90(1): 38-47.

[112] Imwidthaya P. Mycotic keratitis in Thailand. J Med Vet Mycol 1995; 33(1): 81-2.

[113] Passos RM, Cariello AJ, Yu MC, Hofling-Lima AL. Microbial keratitis in the elderly: a 32-year review. Arq Bras Oftalmol 2010; 73(4): 315-9.

[114] Hofling-Lima AL, Guarro J, Freitas D, et al. Clinical treatment of corneal infection due to Fonsecaea pedrosoi--case report. Arq Bras Oftalmol 2005; 68(2): 270-2.

[115] Forster RK, Rebell G, Wilson LA. Dematiaceous fungal keratitis. Clinical isolates and management. Br J Ophthalmol 1975; 59(7): 372-6.
[116] Klotz SA, Penn CC, Negvesky GJ, Butrus SI. Fungal and parasitic infections of the eye. Clin Microbiol Rev 2000; 13(4): 662-85.

[117] Rodriguez-Ares T, De Rojas Silva V, Ferreiros MP, Becerra EP, Tome CC, Sanchez-Salorio M. Acremonium keratitis in a patient with herpetic neurotrophic corneal disease. Acta Ophthalmol Scand 2000; 78(1): 107-9.

[118] Yegneswaran PP, Pai V, Bairy I, Bhandary S. Colletotrichum graminicola keratitis: first case report from India. Indian J Ophthalmol 2010; 58(5): 415-7.

[119] Kaliamurthy J, Kalavathy CM, Ramalingam MD, Prasanth DA, Jesudasan CA, Thomas PA. Keratitis due to a coelomycetous fungus: case reports and review of the literature. Cornea 2004; 23(1): 3-12.

[120] Fernandez V, Dursun D, Miller D, Alfonso EC. Colletotrichum keratitis. Am J Ophthalmol 2002; 134(3): 435-8.

[121] Polack FM, Kaufman HE, Newmark E. Keratomycosis. Medical and surgical treatment. Arch Ophthalmol 1971; 85(4): 410-6.

[122] Xie L, Zhai H, Zhao J, Sun S, Shi W, Dong X. Antifungal susceptibility for common pathogens of fungal keratitis in Shandong Province, China. Am J Ophthalmol 2008; 146(2): 260-5.

[123] Al-Shakarchi F. Initial therapy for suppurative microbial keratitis in Iraq. Br J Ophthalmol 2007; 91(12): 1583-7.

[124] Green M, Apel A, Stapleton F. Risk factors and causative organisms in microbial keratitis. Cornea 2008; 27(1): 22-7.

[125] Doughman DJ, Leavenworth NM, Campbell RC, Lindstrom RL. Fungal keratitis at the University of Minnesota: 1971-1981. Trans Am Ophthalmol Soc 1982; 80: 235-47.

[126] Thomas PA, Kuriakose T. Keratitis due to Arthrobotrys oligospora Fres. 1850. J Med Vet Mycol 1990; 28(1): 47-50.

[127] Chowdhary A, Singh K. Spectrum of fungal keratitis in North India. Cornea 2005; 24(1): 8-15.

[128] Grover S, Jagtap P, Sharma KD. Mycotic keratitis. Indian J Ophthalmol 1975; 23(2): 7-10.

[129] Marcus L, Vismer HF, van der Hoven HJ, Gove E, Meewes P. Mycotic keratitis caused by Curvularia brachyspora (Boedjin). A report of the first case. Mycopathologia 1992; 119(1): 29-33.

[130] Kunimoto DY, Sharma S, Reddy MK, et al. Microbial keratitis in children. Ophthalmology 1998; 105(2): 252-7.

[131] Wilhelmus KR, Jones DB: Curvularia keratitis. Trans Am Ophthalmol Soc 2001; 99: 111-130; discussion 130-112.

[132] Luque AG, Nanni R, de Bracalenti BJ. Mycotic keratitis caused by Curvularia lunata var. aeria. Mycopathologia 1986; 93(1): 9-12.

[133] Guarro J, Akiti T, Horta RA, et al. Mycotic keratitis due to Curvularia senegalensis and in vitro antifungal susceptibilities of Curvularia spp. J Clin Microbiol 1999; 37(12): 4170-3.

[134] Thew MR, Todd B. Fungal keratitis in far north Queensland, Australia. Clin Experiment Ophthalmol 2008; 36(8): 721-24.

[135] Vajpayee RB, Dada T, Saxena R, et al. Study of the first contact management profile of cases of infectious keratitis: a hospitalbased study. Cornea 2000; 19(1): 52-6.

[136] Inoue N, Toshida H, Mamada N, Kogure N, Murakami A. Contact lens-induced infectious keratitis in Japan. Eye Contact Lens 2007; 33(2): 65-9.

[137] Djalilian AR, Smith JA, Walsh TJ, Malech HL, Robinson MR Keratitis caused by Candida glabrata in a patient with chronic granulomatous disease. Am J Ophthalmol 2001; 132(5): 782-3.

[138] Schein OD, Ormerod LD, Barraquer E, et al. Microbiology of contact lens-related keratitis. Cornea 1989; 8(4): 281-5.

[139] Hassan HM, Papanikolaou T, Mariatos G, Hammad A, Hassan H. Candida albicans keratitis in an immunocompromised patient. Clin Ophthalmol 2010; 4: 1211-15.

[140] Ahn M, Yoon KC, Ryu SK, Cho NC, You IC. Clinical aspects and prognosis of mixed microbial (bacterial and fungal) keratitis. Cornea 2011; 30(4): 409-13.

[141] Guerra R, Cavallini GM, Longanesi L, et al. Rhodotorula glutinis keratitis. Int Ophthalmol 1992; 16(3): 187-90.

[142] Ludwig A. The use of mucoadhesive polymers in ocular drug delivery. Adv Drug Del Rev 2005; 57(11): 1595-639.

[143] Gugnani HC, Talwar RS, Njoku-Obi AN, Kodilinye HC. Mycotic keratitis in Nigeria. A study of 21 cases. Br J Ophthalmol 1976; 60(9): 607-13.

[144] Gonawardena SA, Ranasinghe KP, Arseculeratne SN, Seimon CR, Ajello L. Survey of mycotic and bacterial keratitis in Sri Lanka. Mycopathologia 1994; 127(2): 77-81. 
[145] Anderson KL, Mitra S, Salouti R, Pham TA, Taylor HR. Fungal keratitis caused by Paecilomyces lilacinus associated with a retained intracorneal hair. Cornea 2004; 23(5): 516-21.

[146] Williams G, McClellan K, Billson F. Suppurative keratitis in rural Bangladesh: the value of gram stain in planning management. Int Ophthalmol 1991; 15(2): 131-5.

[147] Coster DJ, Badenoch PR. Host, microbial, and pharmacological factors affecting the outcome of suppurative keratitis. $\mathrm{Br} \mathrm{J}$ Ophthalmol 1987; 71(2): 96-101.

[148] Levey SB, Katz HR, Abrams DA, Hirschbein MJ, Marsh MJ. The role of cultures in the management of ulcerative keratitis. Cornea 1997; 16(4): 383-6.

[149] Norina TJ, Raihan S, Bakiah S, Ezanee M, Liza-Sharmini AT, Wan Hazzabah WH. Microbial keratitis: aetiological diagnosis and clinical features in patients admitted to Hospital Universiti Sains Malaysia. Singapore Med J 2008; 49(1): 67-71.

[150] Alexandrakis G, Alfonso EC, Miller D. Shifting trends in bacterial keratitis in south Florida and emerging resistance to fluoroquinolones. Ophthalmology 2000; 107(8): 1497-502.

[151] Cheng KH, Leung SL, Hoekman HW, et al. Incidence of contactlens-associated microbial keratitis and its related morbidity. Lancet 1999; 354(9174): 181-5.

[152] Bharathi MJ, Ramakrishnan R, Shivakumar C, Meenakshi R, Lionalraj D. Etiology and antibacterial susceptibility pattern of community-acquired bacterial ocular infections in a tertiary eye care hospital in south India. Indian J Ophthalmol 2010; 58(6): 497507.

[153] Saeed A, D'Arcy F, Stack J, Collum LM, Power W, Beatty S. Risk factors, microbiological findings, and clinical outcomes in cases of microbial keratitis admitted to a tertiary referral center in ireland. Cornea 2009; 28(3): 285-92.

[154] Roussel TJ, Osato MS, Wilhelmus KR, Capnocytophaga keratitis. Br J Ophthalmol 1985; 69(3): 187-8.

[155] Hirst LW, Harrison GK, Merz WG, Stark WJ. Nocardia asteroides keratitis. Br J Ophthalmol 1979; 63(6): 449-54.

[156] Sanz-Marco E, Lopez-Prats MJ, Garcia-Delpech S, Udaondo P, Diaz-Llopis M. Fulminant bilateral Haemophilus influenzae keratitis in a patient with hypovitaminosis A treated with contaminated autologous serum. Clin Ophthalmol 2011; 5: 71-3.

[157] Miedziak AI, Miller MR, Rapuano CJ, Laibson PR, Cohen EJ. Risk factors in microbial keratitis leading to penetrating keratoplasty. Ophthalmology 1999; 106(6): 1166-70; discussion 1171.

[158] Penland RL, Boniuk M, Wilhelmus KR. Vibrio ocular infections on the U.S. Gulf Coast. Cornea 2000; 19(1): 26-9.

[159] Butt AA, Figueroa J, Martin DH. Ocular infection caused by three unusual marine organisms. Clin Infect Dis 1997; 24(4): 740.

[160] Yu HS, Kong HH, Kim SY, Hahn YH, Hahn TW, Chung DI. Laboratory investigation of Acanthamoeba lugdunensis from patients with keratitis. Invest Ophthalmol Vis Sci 2004; 45(5): 1418-26.

[161] Walochnik J, Haller-Schober E, Kolli H, Picher O, Obwaller A, Aspock H. Discrimination between clinically relevant and nonrelevant Acanthamoeba strains isolated from contact lenswearing keratitis patients in Austria. J Clin Microbiol 2000; 38(11): 3932-6.

[162] McClellan K, Howard K, Niederkorn JY, Alizadeh H. Effect of steroids on Acanthamoeba cysts and trophozoites. Invest Ophthalmol Vis Sci 2001; 42(12): 2885-93.

[163] Aitken D, Hay J, Kinnear FB, Kirkness CM, Lee WR, Seal DV. Amebic keratitis in a wearer of disposable contact lenses due to a mixed Vahlkampfia and Hartmannella infection. Ophthalmology 1996; 103(3): 485-94

[164] Thygeson P. Ocular viral diseases. Med Clin North Am 1959; 43 : 1419-40.

[165] Pavlopoulos GP, Giannakos GI, Theodosiadis PG, Moschos MM, Iliakis EK, Theodosiadis GP. Rubeola keratitis: a photographic study of corneal lesions. Cornea 2008; 27(4): 411-6.

[166] Ruben FL, Lane JM. Ocular vaccinia. An epidemiologic analysis of 348 cases. Arch Ophthalmol 1970; 84(1): 45-8.

[167] Epstein RJ, Seedor JA, Dreizen NG, et al. Penetrating keratoplasty for herpes simplex keratitis and keratoconus. Allograft rejection and survival. Ophthalmology 1987; 94(8): 935-44. 